\title{
The fight is on: military metaphors for cancer may harm patients
}

\author{
Margaret McCartney general practitioner, Glasgow
}

Cancer Research UK (CRUK) wants people to "show us your fight face" by posting their selfies on Twitter to raise money for its "life-saving research to bring forward the day when all cancers are cured." In Glasgow, earlier this year, an advertising agency working for the Beatson Cancer Centre declared on billboards, "Be full of hope. Be courageous. Be ready to fight," adding that it was "determined to beat cancer."

CRUK says it has a "war chest"1 for research funding. Many patient-bloggers on its website describe "victories" over cancer. The charity describes research that "recruits viruses for cancer battle," under the heading "Let's beat cancer sooner."" The advertising agency for CRUK's fun runs said that it aimed to transform them "from a gathering of women in pink" to an "army who run, dance, and sing." The agency said lines like "Cancer! We're coming to get you" and "Oi! Cancer! You. Me. Outside. Now" were "designed to have cancer quaking in its rubbish boots.",

Military metaphors appeal because they make grey shades distinct and the "enemy" clear. But they are also prejudicial. Susan Sontag pointed this out in her Illness as Metaphor in 1978; we have not made much progress since. The late journalist John Diamond wrote in 1999, "My antipathy to the language of battles and fights has ... everything to do with a hatred of the sort of morality which says that only those who fight hard against their cancer survive it or deserve to survive it-the corollary being that those who lose the fight deserve to do so." His view is also evidence based: a "fighting" coping style is not associated with improved survival. ${ }^{5}$

It's astonishing, then, that Diamond's view has gained so little respect among fundraisers. It's one thing to accept individual patients' use of war metaphors for themselves; it's another to encourage their widespread use.

And what of the potential harms? How many patients fear that they are not "a fighter" and will be damaged by that kind of pressure? One series of interviews found that patients thought that doctors had promoted a "positive attitude" but that this left little room to express fear, shock, or sadness. ${ }^{6}$
Many types of cancers are not curable; thousands of people are living with "the enemy." In the unlikely event that "all cancers are cured," humans will still die. No one needs to be told what their attitude to illness should be-least of all by advertising agencies. $^{\prime}$

Competing interests: I have read and understood the BMJ Group policy on declaration of interests and declare the following interests: I'm an NHS GP partner, with income partly dependent on QOF points. I'm a part time undergraduate tutor at the University of Glasgow. I've authored a book and earned from broadcast and written freelance journalism. I'm an unpaid patron of Healthwatch. I make a monthly donation to Keep Our NHS Public. I'm a member of MedAct. I'm occasionally paid for time, travel, and accommodation to give talks or have locum fees paid to allow me to give talks but never for any drug or public relations company. I was elected to the national council of the Royal College of General Practitioners in 2013.

Provenance and peer review: Commissioned; not externally peer reviewed.

Follow Margaret McCartney on Twitter, @mgtmccartney

Cancer Research UK increases war chest by 50 per cent to open new fronts to tackle cancers' challenges. Press release. Cancer Research UK. 29April 2014. www. cancerresearchuk.org/about-us/cancer-news/press-release/cancer-research-uk-increaseswar-chest-by-50-per-cent-to-open-new-fronts-to-tackle-cancers

2 Rigby E. Cancer Research UK recruits viruses for cancer battle. Science blog. Cancer Research UK. 2 June 2009. http://scienceblog.cancerresearchuk.org/2009/06/02/cancerresearch-uk-recruits-viruses-fo-cancer-battle/

Race for Life-cancer, we're coming to get you. Mother London. www.motherlondon.com creative/race-for-life-cancer-were-coming-to-get-you

4 Diamond J. C: Because cowards get cancer too . Vermillion, 1999

5 Petticrew M, Bell R, Hunter D. Influence of psychological coping on survival and recurrence in people with cancer: systematic review. BMJ 2002;325:1066.

6 Byrne A, Ellershaw J, Holcombe C, Salmon P. Patients' experience of cancer: evidence of the role of 'fighting' in collusive clinical communication. Patient Educ Couns 2002;48;15-21. www.pec-journal.com/article/S0738-3991(02)00094-0/abstract 7 Wiggins NM. Stop using military metaphors for disease. BMJ 2012;345:e4706. 